\title{
Biofouling and control approaches in membrane bioreactors
}

Lijuan Deng ${ }^{\mathrm{a}, \mathrm{b}}$, Wenshan Guo ${ }^{\mathrm{b}, \mathrm{d}}$, Huu Hao Ngo ${ }^{\mathrm{b}, \mathrm{d}^{*}}$, Hongwei Zhang ${ }^{\mathrm{a}, \mathrm{c}}$, Jie Wang ${ }^{\mathrm{a}}$, Jianxin $\mathrm{Li}^{\mathrm{c}, \mathrm{d}}$, Siqing Xia ${ }^{\mathrm{d}}$, Yun $\mathrm{Wu}^{\mathrm{a}}$

${ }^{a}$ School of Environmental and Chemical Engineering, Tianjin Polytechnic University, Tianjin 300387, China

${ }^{\mathrm{b}}$ Centre for Technology in Water and Wastewater, School of Civil and Environmental Engineering, University of Technology Sydney, Broadway, NSW 2007, Australia

${ }^{\mathrm{c}}$ State Key Laboratory of Separation Membranes and Membrane Processes, Tianjin Polytechnic University, Tianjin 300387, China

${ }^{\mathrm{d}}$ Membrane Bioreactor Centre, College of Environmental Science and Engineering, Tongji

University, State Key Lab. of Pollution Control and Resource Reuse, Shanghai, 200092, China

*Corresponding author, Email: h.ngo@ uts.edu.au or ngohuuhao121@gmail.com; Tel: +61-2-

95142745

\section{Abstract}

Membrane fouling (especially biofouling) as a critical issue during membrane reactor (MBR) operation has attracted much attention in recent years. Although previous review papers have presented different aspects of MBR's fouling when treating various wastewaters, the information related to biofouling in MBRs has only simply or partially reviewed. This work attempts to give a more comprehensive and elaborate explanation of biofilm formation, biofouling factors and control approaches by addressing current achievements. This also suggests to a better way in controlling biofouling by developing new integrated MBR systems, novel flocculants and biomass carriers.

Keywords: Membrane bioreactor; Biofouling; Sludge properties; Operating conditions; Biofouling control strategies 


\section{Introduction}

Membrane fouling, especially biofouling, is what primarily hinders the application and development of membrane biroeactors (MBRs) (Meng et al., 2009). Recently, some review papers have analysed membrane fouling in MBRs for wastewater treatment. Meng et al. (2009) addressed fouling behaviour, fouling factors and controlling strategies of MBRs for municipal and industrial wastewater treatment. However, specific information regarding effects of sludge conditions (e.g. mixed liquor suspended solids (MLSS), sludge viscosity) on membrane fouling and impacts of bound EPS on sludge characteristics (e.g. flocculation ability, hydrophobicity) was not clearly provided.

The fouling characterisation methods, results and fouling mitigation strategies were updated and critically re-evaluated by Drews (2010). Nevertheless, some key parameters affecting membrane fouling were not articulated in this review, such as EPS and HRT. Le-Clech (2010) reported MBR applications, design and removal performance, and current research trends. However, this review paper did not discuss the HRT as one of the main parameters affecting soluble microbial products (SMP) and membrane fouling. An overview on the current application of MBR technology for industrial wastewater treatment was presented by Lin et al. (2012), who reviewed and analysed more than 300 scientific publications on MBRs (including anaerobic MBR $(\mathrm{AnMBR}))$ for industrial wastewater treatment. However, since the objective of this review was not to comprehensively present membrane fouling mechanisms and characteristics, membrane fouling (including fouling factors and membrane fouling propensity) was only briefly mentioned together with some unique and significant findings concerning membrane fouling control measures. Although Mutamim et al. 
(2012) reviewed the performance of MBRs in treating high strength industrial wastewater, which covered the operation, constraints and fouling mitigation strategies in general views, the information was inadequate regarding the influence of membrane properties, biomass and operational conditions on membrane fouling along with membrane fouling mitigation. Similarly, a later review did not clearly address the relationship between EPS/SMP and membrane fouling (Mutamim et al., 2013).

To date, several review papers have been published on biofouling in MBRs. Guo et al. (2012) undertook a holistic review on different membrane fouling phenomena during water and wastewater treatment, but only partially discussed biofouling in membrane filtration processes. Wu and Fane (2012) reviewed factors (feed characteristics, oxygen level, temperature, steady or unsteady-state operation) affecting microbial behaviors, characterisation technologies of biofoulants and strategies for controlling microbial relevant fouling (e.g. application of ozone, etc.) in MBRs when treating industrial and municipal wastewater. Unfortunately, this review did not document the effects of HRT on characteristics of microbial flocs and their metabolic products, which affected membrane fouling. Nguyen et al. (2012a) highlighted the underlying causes of membrane biofouling, emphasised the role of EPS in membrane biofouling, and discussed recent developments in biofilm examination and biofouling control in water and wastewater treatment. However, this review did not elaborate on the impacts of operating conditions (i.e. HRT) and sludge characteristics (i.e. MLSS) on membrane fouling. Later on, a comprehensive review conducted by Wang et al. (2013a) focused on membrane fouling caused by EPS, including their secretion, transformation, release, and adsorption in MBRs for municipal and industrial wastewater treatment. 
Nevertheless, new knowledge on sludge properties regarding membrane fouling, such as MLSS and floc size was not articulated.

This review paper is dedicated to broader and more detailed analyses of the main aspects of biofouling in MBRs based on current research achievements. A more thorough discussion is carried out with respect to biofilm formation, the interactions among the biomass characteristics, operating conditions, feedwater characteristics and membrane properties, and their effects on membrane biofouling. Furthermore, some helpful and reasonable suggestions are given in view of biofouling minimisation. Finally, emerging fouling control strategies (e.g. membrane cleaning, biomass carriers, flocculants, etc.) are presented along with future research trends in membrane biofouling.

\section{Biofouling and its effects on membrane systems}

Of the six principle fouling mechanisms (pore blocking, cake formation, concentration polarization, organic adsorption, inorganic precipitation and biofouling), biofouling is the most complicated since it is associated with undesirable deposition, growth and metabolism of bacterial cells or flocs on membrane surface and/or inside membrane pores (Guo et al., 2012). Generally, six steps involved in biofilm formation are shown in Fig. 1 (Bitton, 2005; Guo et al., 2012): (1) formation of a conditioning film on the pristine surface after exposing the surface to the feed including organic matters; (2) transport of microorganisms and planktonic cells to conditioned surface by diffusion, convection, turbulent eddy, and chemotaxis; (3) adhesion of microorganisms to conditioned surface as a result of the negatively free energy of adhesion, the balanced force between Lifshitz-Van der Waals forces and repulsive or electrostatic forces from 
both microbial and substratum surfaces, or hydrophobic interactions; (4) continuous attachment and adsorption of microorganisms on the surface due to the presence of EPS which enables microorganisms to be adhered to the surface and bond with the biofilm; (5) biofilm growth and accumulation; and (6) formation of a three-dimension biofilm.

\section{Fig. 1.}

The effects of biofouling on the performance of membrane systems are as follows:

(1) decreased membrane permeability resulting from bacterial attachment and subsequent growth on the membrane surface; (2) precipitation of calcium carbonate at an elevated $\mathrm{pH}$; (3) accumulation of abiotic particles because of microorganism adhesion or an enzymatic attack on the membrane or the glue lines; and (4) concentrated polarization by biofilms on the membrane surface (Dreszer et al., 2013). During the MBR process, biofouling results in poorer membrane permeability, more serious flux decline, more frequent membrane replacement and higher operational and maintenance costs.

\section{Factors affecting biofouling in MBR}

The biofouling factors discussed in this review paper include mixed liquor properties, operating conditions, feed water characteristics and membrane properties.

\subsection{Mixed liquor properties}

\subsubsection{Bound extracellular polymeric substances (EPS)}

Bound EPS, which are mainly composed of polysaccharides $\left(\mathrm{EPS}_{\mathrm{C}}\right)$ and proteins $\left(\mathrm{EPS}_{\mathrm{P}}\right)$, played a pivotal role in membrane biofouling development, especially cake layer formation. In a MBR under long-term operation, biocake on the membrane surface 
mainly consisted of microbial cells and EPS, which evolved from an initially reversible fouling inducing via the accumulation of easily removable organic substances to the subsequent development of irreversible fouling; this in turn is due to consistently increasing EPS levels (Domínguez et al., 2012).

Tian et al. (2011a) observed that more severe membrane fouling occurred during filtration of bulking sludge, which was linked to the abundance of filamentous bacteria and presence of more cell-bound EPS than that for the normal sludge. Excessive EPS would deteriorate the structure of sludge flocs and reduce their bioflocculation ability. Moreover, a higher EPS $/$ EPS $_{\mathrm{C}}$ ratio in the bulking sludge increased floc hydrophobicity. Thus, the sludge flocs having more EPS and higher $\mathrm{EPS}_{\mathrm{P}} / \mathrm{EPS}_{\mathrm{C}}$ ratio could aggravate membrane fouling by their deposition on the membrane surface. Liu et al. (2012) discovered that higher levels of loosely bound EPS (LB-EPS) resulted in a poorer flocculability and a lower settleability of activated sludge, and the formation of looser sludge flocs, which increased cake layer resistance, total membrane resistance and TMP development. It was also pointed out that a high concentration of LB-EPS obtained at a high proportion of dead cells in activated sludge stimulated the generation of fine particles and attachment of small flocs onto the membrane. This gave rise to the formation of a dense cake layer on the membrane surface and serious membrane fouling. However, tightly bound EPS (TB-EPS) reduced the incidence of membrane fouling. A greater TB-EPS to LB-EPS ratio reflected a high flocculability of activated sludge, thus encouraging the generation of large flocs, less membrane fouling and lower total membrane resistance (Azami et al., 2011). 


\subsubsection{Soluble microbial products (SMP) and biopolymer clusters (BPC)}

When compared to other sludge characteristics (e.g. MLSS, particle size distribution, bound EPS), SMP had the strongest relationship with membrane fouling rate (dTMP/dt) (Zhang et al., 2015a). SMP (or soluble EPS) could be readily deposited and adsorbed on and/or into the membrane owing to the permeation drag and higher Brownian diffusion. In addition, the attachment of SMP to membrane surface could be achieved by considerably high attractive interaction energy and through overcoming high repulsive energy barrier. Thus, they would encourage the formation of a gel layer, cause membrane pore blocking, and penetrate into the pores and spaces between particles in the cake layer. In the gel and cake layers, SMP with macromolecular character constituted the major soluble organic substances. When compared to the cake layer, the gel layer possessed more SMP, which had unusually high specific filtration resistance being almost 100 times higher than the cake layer. These effects led to serious membrane fouling and decreased permeate flowrate (Hong et al., 2014; Wang et al., 2012; Wu and Huang, 2009). Current studies revealed that the molecular weight (MW) distribution of SMP impacted membrane fouling. Shen et al. (2010) and Shen et al. (2012) pointed out that large-molecular-weight fraction (MW > $100 \mathrm{kDa})$ in hydrophilic substances (HIS) of SMP, which mainly consisted of the polysaccharidelike substances, engendered severe flux decline and pore plugging. Shen et al. (2010) concluded that size exclusion played a key role in irreversible fouling of HIS.

Membrane fouling was also significantly influenced by SMP compositions (especially proteins/polysaccharides $\left(\mathrm{SMP}_{\mathrm{P}} / \mathrm{SMP}_{\mathrm{C}}\right)$ ratio). Yao et al. (2011) found that higher $\mathrm{SMP}_{\mathrm{P}} / \mathrm{SMP}_{\mathrm{C}}$ ratio reduced irreversible fouling and promoted the interaction of $\mathrm{SMP}_{\mathrm{P}}$ and $\mathrm{SMP}_{\mathrm{C}}$ for cake layer formation on the membrane's surface. However, Gao et 
al. (2013a) reported that when operating MBRs for treating industrial wastewaters from a local thermomechanical pulping mill, higher $\mathrm{SMP}_{\mathrm{P}} / \mathrm{SMP}_{\mathrm{C}}$ ratio negatively influenced the cake layer structure (i.e. higher thickness, lower porosity, smaller floc size) and increased the filtration resistance. Besides, Tian et al. (2011b) conducted a series of stirred dead-end filtration tests to evaluate the fouling potential of biomass-associated products (BAP) and utilization-associated products (UAP). The results implied that membane interception induced almost complete reduction of proteins and partial decrease of polysaccharides of UAP and BAP in the permeate. Membrane foulants were mainly composed of proteins and polysaccharides. The modelling work demonstrated that cake filtration and complete blockage were primary fouling mechanisms for BAP and UAP filtration, respectively. This suggested that fouling potential for the UAP was higher than that for BAP.

Fig. 2 shows a schematic illustration of the correlation between SMP and BPC in MBRs. The interception of BPC by sludge layer, the aggregation and clustering of SMP and small BPC as well as attachment of loose EPS within the sludge layer were responsible for the formation and growth of BPC in sludge cake. BPC acted as glue and thus prompted the biomass deposition on the membrane surface, which in turn accelerated the formation of sticky and impermeable sludge cake. It resulted in serious membrane fouling and high filtration resistance of the cake layer. On the other hand, BPC could be detached from the membrane surface into the sludge suspension by the turbulent shear resulting from aeration in MBR. Large BPC of activated sludge in MBR will deteriorate due to the fluid turbulence, generating smaller SMP segments. Subsequently, both SMP and BPC were in a transformable state regarding their size 
distribution and demontrated a balanced size distribution in mixed lquor in MBR (Sun et al., 2008; Wang and Li, 2008).

Fig. 2.

\subsubsection{Mixed liquor suspended solids (MLSS) and sludge viscosity}

Some studies have explored the relationship between sludge viscosity and MLSS concentration as well as their impacts on membrane biofouling. Table 1 displays the effects of MLSS concentration on biofouling in MBR. Higher MLSS resulted in more retention of sludge particles, colloids, macromolecular matter and microbial products in the bioreactor. Higher sludge viscosity moderated the effects of air bubbling on membrane fouling reduction, discouraged membrane fibre vibration, and allowed larger air bubbles to move at low rise velocity. Moreover, higher viscosity also dampened the back transport effect and increased the net force towards the membrane surface, leading to the deposition of sludge flocs, biopolymers and smaller particles on the membrane's surface. Thus, activated sludge with higher MLSS levels and viscosity will compromise membrane performance in terms of more rapid flux decline, lower membrane filterability, higher TMP and greater membrane fouling resistance (Kornboonraksa and Lee, 2009; Lay et al., 2010; Meng et al., 2007).

\section{Table 1.}

Current studies have pointed out that MLSS of $10 \mathrm{~g} / \mathrm{L}$ was a critical point with respect to membrane fouling. Wu and Huang (2009) suggested that high MLSS concentration $(>10 \mathrm{~g} / \mathrm{L})$ stimulated a wide-range increase in sludge viscosity, which showed a remarkable impact on membrane filterability (poor filterability). Lousada- 
Ferreira et al. (2010) collected activated sludge from full-scale MBRs and submitted the sludge to cross-flow filtration by employing the same membrane and operating conditions. MLSS concentrations were varied (3.6-18.3 $\mathrm{g} / \mathrm{L}$ ) by diluting the original samples. MBR activated sludge at higher MLSS concentration (> $10 \mathrm{~g} / \mathrm{L})$ adsorbed smaller particles $(<20 \mu \mathrm{m})$ and generated dilutions with worse filterability. Very different results were obtained for the activated sludge samples at MLSS concentrations below $10 \mathrm{~g} / \mathrm{L}$, which could not entrap particles.

\subsubsection{Floc size}

It has been indicated that the permeate flux (membrane permeability) was positively correlated with sludge floc size (Kornboonraksa and Lee, 2009). From the hydrodynamic viewpoint, large flocs could be dragged away from the membrane by high shear-induced diffusion and inertial force as well as lower Brownian diffusion. The deposition of larger and looser sludge flocs on the membrane encouraged the formation of a more porous and permeable cake layer, thus reducing fouling resistance. On the other hand, Brownian diffusion controlled the motions of small flocs at lower shear stress (Dizge et al., 2011a; Pan et al., 2010). It is noted that membrane pore size should be also taken into account when investigating the effects of sludge floc size on membrane fouling. Shen et al. (2015) observed that when membrane pore size was 0.3 $\mu \mathrm{m}$ and most of flocs were larger than $1 \mu \mathrm{m}$, less obvious pore clogging occurred. The thermodynamic analyses revealed that the specific energy barrier was slightly higher when decreasing the sludge floc size, while smaller flocs promoted an increase in the attractive specific interaction energy in contact. Hence, the whole effect favoured the deposition of small flocs on the membrane and the subsequent formation of a less 
porous cake layer with small pore size, which in turn increased hydraulic cake resistance and osmotic pressure-induced resistance as a result of more biopolymer matters being retained in the pores of the cake layer.

\subsection{Operating conditions}

\subsubsection{Sludge retention time (SRT)}

It has been widely accepted that SRT is one of the most critical operating parameters during MBR operation. Table 2 summarises the effects of SRT on biofouling in MBR. When treating synthetic wastewater, SRT affected the microbial community and further activated sludge characteristics (e.g. MLSS concentration, EPS properties), which influenced the hydrodynamic conditions (the dynamic balance between shear force and permeate drag along the membrane surface). It in turn governed cake layer development and membrane fouling propensity. At infinite SRT, membrane fouling (cake-fouling) was more severe due to the presence of smaller floc size and more EPS than those at SRTs of 10 and $30 \mathrm{~d}$ when operating at a high flux of $30 \mathrm{~L} / \mathrm{m}^{2} \cdot \mathrm{h}$ (Wu et al., 2011a). Chen et al. (2012) suggested that SRT should be

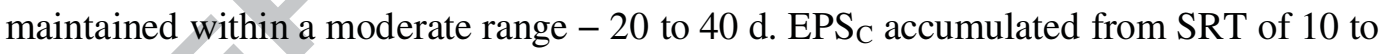
$40 \mathrm{~d}$ caused by endogenous respiration, and increase in microbial death and intracellular polymers. Meanwhile a prolonged SRT above $40 \mathrm{~d}$ led to a decrease in $\mathrm{EPS}_{\mathrm{C}}$ concentration considering that inadequate nutrients supplied for microorganisms

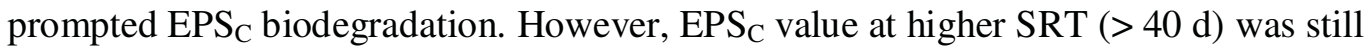
higher than that at lower SRT $(<40 \mathrm{~d})$. On the other hand, the reduction of supernatant COD (SMP) was obtained at shorter SRT $(<40 \mathrm{~d})$ because of their biodegradation. 
When SRT was extended, SMP accumulated due to the dissolution of intracellular substances induced by the breakdown of dead cells and less SMP biodegradation.

Table 2.

When treating a pharmaceutical process wastewater at various SRTs $(15 \mathrm{~d}, 30 \mathrm{~d}$, without sludge wasting (WSW)), both permeate volumes and steady state fluxes of the submerged MBR (SMBR) increased at longer SRTs. This could be ascribed to the decreased membrane fouling because of lower concentrations of EPS and SMP (including protein and carbohydrate fractions). Total fouling resistance $\left(\mathrm{R}_{\mathrm{T}}\right)$ and cake resistance $\left(R_{C}\right)$ decreased with increasing SRTs. $R_{C}$ was the major contributor for $R_{T}$ under the WSW, while for 15 and 30 days of SRT, membrane pore resistance $\left(\mathrm{R}_{\mathrm{P}}\right)$ increased when compared to the WSW (Kaya et al., 2013). Zhang et al. (2015a) suggested that an anaerobic-oxic MBR at SRT of $30 \mathrm{~d}$ displayed better filtration performance compared to SRTs of 10 and $90 \mathrm{~d}$ when treating campus sewage. Median particle size and MLSS concentration in the MBRs followed the order of SRT $=90 \mathrm{~d}>$ SRT $=30 \mathrm{~d}>\mathrm{SRT}=10 \mathrm{~d}$. SMP concentrations were higher at SRTs of 10 and $90 \mathrm{~d}$ than those at SRT of $30 \mathrm{~d}$. SRT of $10 \mathrm{~d}$ gave rise to pore blocking and serious irreversible fouling, while the formation of a cake layer and severe reversible fouling were attained at SRT of $90 \mathrm{~d}$.

Based on investigations above and taking into account the suggestion by Meng et al. (2009), too long or short SRT was no advantage when attempting to control fouling. The selection of SRT for MBR operation depended on membrane properties (e.g. pore size), HRT and types of wastewater. MBR should be operated at SRT of 20-40 d when treating synthetic wastewater, while for real wastewater treatment, it is recommended that SRT be controlled at 20-30 d or WSW. 


\subsubsection{Hydraulic retention time $(H R T)$}

HRT is another key operating parameter having a pronounced impact on membrane fouling (especially biofouling) during the MBR process, which can alter mixed liquor properties, for instance EPS, SMP and sludge stability (Guo et al., 2012). Recent studies compared MBR performance at various HRTs. When operating a lab-scale combined system consisting of an anoxic tank and an aerobic MBR for digested wastewater treatment, more severe membrane fouling and higher filtration resistance and fouling rate were observed with decreasing HRT from 8 to $2.5 \mathrm{~h}$. At shorter HRTs of 4 and 2.5 $\mathrm{h}$, the membrane surface was covered by thick flocs that blocked most of membrane pores (Gao et al., 2012). Babatouli et al. (2014) investigated the performance of an MBR pilot plant treating industrial wastewater at a short HRT of $20 \mathrm{~h}$. Their results indicated that when compared to longer HRT of $24 \mathrm{~h}$, shorter HRT of $19 \mathrm{~h}$ increased the fouling rate and total concentrations of EPS and SMP as a consequence of more substrate being made available for biomass at higher F/M ratio.

\subsubsection{Dissolved oxygen (DO)}

Air flow rate or DO is a principle operating parameter that determines the hydrodynamic conditions, sludge characteristics (i.e. EPS, SMP), and membrane fouling. When operating at low airflow rate or DO, cake layer would be formed by the deposition of MLSS on the membrane, which could not be removed by the low shear stress. Low DO also decreased aerobic activity of microorganisms, which reduced the generation of EPS or increased anaerobic degradation of EPS, leading to the sludge's deflocculation. An appropriately high DO concentration could promote sludge bioflocculation, and enhance sludge characteristics and membrane performance. However, extremely high aeration intensity would break up sludge flocs, facilitate the 
release of EPS, SMP and colloids, and deteriorate the filterability. It undermined membrane performance because of the accumulation of colloids and solute within/on the membrane (Braak et al., 2011; Faust et al., 2014). Gao et al. (2011) indicated that more severe membrane fouling at low DO concentration $(0.5 \mathrm{mg} / \mathrm{L})$ was ascribed to more EPS in membrane biocake than that at high DO concentation $(4 \mathrm{mg} / \mathrm{L})$.

At different DO levels, microbial community structure in mixed liquor and biocake governed membrane fouling. The microbial community structure in biocake displayed larger variations than that in mixed liquor. De Temmerman et al. (2015) monitored a default aeration situation (reference) at DO of around $2 \mathrm{mg} / \mathrm{L}$ and an elevated aeration situation (disturbance) in two identical MBRs, respectively. The later one was accomplished by manually controlling aeration at DO concentration of around $4 \mathrm{mg} / \mathrm{L}$ for $18 \mathrm{~h}$, after which the DO level immediately decreased to $2 \mathrm{mg} / \mathrm{L}$ (the average setting, the reference situation). At high fine bubble aeration intensity, higher concentrations of SMP, biopolymers, and submicron particles (10-1000 nm) were obtained together with a shift in the particle size distribution (PSD) (3-300 $\mu \mathrm{m})$ towards smaller sludge flocs. As a result, the system demonstrated higher total fouling due to the formation of a less permeable cake layer and higher irreversible fouling mainly resulted from pore blocking. Overall, an "optimal" air flow rate or DO concentration should be determined considering loose/tight MBR configurations, and aeration time, position and mode (e.g. cyclic aeration on/off).

\subsubsection{Temperature}

It demonstrated that the decreased temperature $\left(7,15\right.$, and $\left.25^{\circ} \mathrm{C}\right)$ prompted the accumulation of polysaccharides in the soluble fraction of mixed liquor and a shift in floc size of the soluble fraction towards smaller particles. This in turn exacerbated the 
occurrences of pore blocking/pore narrowing and membrane fouling (van der Brink et al., 2011). Gao et al. (2013b) found that in both mixed liquor and biocake, the decrease in temperature from 30 to $20^{\circ} \mathrm{C}$ hastened the reduction of EPS and SMP (mainly EPS and $\left.\mathrm{SMP}_{\mathrm{P}}\right)$. However, an additional decline in temperature to $10{ }^{\circ} \mathrm{C}$ resulted in an obvious rise of EPS, SMP, $\mathrm{EPS}_{\mathrm{P}}$ and $\mathrm{SMP}_{\mathrm{P}}$, thus aggravating membrane fouling. Both $\mathrm{EPS}_{\mathrm{C}}$ in biocake and $\mathrm{SMP}_{\mathrm{C}} / \mathrm{SMP}_{\mathrm{P}}$ in mixed liquor were significantly correlated with temperature and filtration resistance. Another study implied that during the operating period $\left(8.7-19.7^{\circ} \mathrm{C}\right)$, the decline in temperature encouraged the increase of EPS and SMP through promoting their formation and lowering hydrolysis ability of microorganisms, which triggered serious membrane fouling.

\subsection{Feedwater characteristics}

\subsubsection{Organic loading rate $(O L R)$ or food/microorganism (F/M) ratio}

The OLR or F/M ratio could change microbial behaviours, microbial properties and biomass characteristics in mixed liquor (e.g. MLSS, particle size, viscosity, floc structure, EPS and SMP) and membrane biofilm (e.g. bacteria community), thus influencing membrane biofouling. As compared to the low loading ( $0.33 \mathrm{~g}$ $\mathrm{COD} /(\mathrm{gVSS} \cdot \mathrm{d})$ ), earlier and faster membrane fouling (irreversible fouling) was attained under the high loading $(0.52 \mathrm{~g} \mathrm{COD} /(\mathrm{gVSS} \cdot \mathrm{d}))$ because of higher EPS contents, substantially thick biofilm, and the dominance of two bacteria Betaproteobacteria and Bacteroidetes in the biofilm during the long-term operation (Xia et al., 2010). Wu et al. (2011b) reported that at various organic loadings, variations in F/M ratios and DO levels led to changes in bacteria communities and EPS generation during the initial operational period. At the steady state, a slightly lower membrane fouling in the low-organic- 
loading MBR $\left(0.57 \mathrm{~kg} \mathrm{COD} / \mathrm{m}^{3} \cdot \mathrm{d}\right)$ but remarkably higher fouling and specific fouling reisistance in the high-organic-loading MBR $\left(2.28 \mathrm{~kg} \mathrm{COD} / \mathrm{m}^{3} \cdot \mathrm{d}\right)$ were achieved. This was comparable to the medium-organic-loading MBR $\left(1.14 \mathrm{~kg} \mathrm{COD} / \mathrm{m}^{3} \cdot \mathrm{d}\right)$ at a high flux of $30 \mathrm{~L} / \mathrm{m}^{2} \cdot \mathrm{h}$. Higher organic loading increased EPS levels and facilitated the formation of cake fouling on the membrane surface, whereas the increased organic loading within a moderate range $\left(0.57-1.14 \mathrm{~kg} \mathrm{COD} / \mathrm{m}^{3} \cdot \mathrm{d}\right)$ helped to control fouling.

On the other hand, a short-term starvation (low F/M ratio of $0.05 / \mathrm{d}$ ) stimulated activated sludge to consume UAPs for exogenous metabolisms and retaining their activity, which was conducive to fouling reduction as a result of SMP decline. However, a long-term starvation would prompt the release of large amounts of high-molecular-weight BAP (humic-acid substances) from SMP, which clogged the overall membrane surface and subsequently led to serious fouling (Wu and Lee, 2011).

\subsubsection{Carbon to nitrogen or carbon to phosphorus ratio $(C / N$ or $C / P)$}

Current studies focused on nutrient parameters, such as C/N, C/P ratios, which had an effect on bacteria communities and sludge characteristics, thereby influencing the potential for membrane biofouling. Compared to higher $\mathrm{C} / \mathrm{N}$ ratio of 10:1 (lower $\mathrm{NH}_{4}{ }^{+}$concentrations), higher concentrations of $\mathrm{NH}_{4}{ }^{+}-\mathrm{N}$ in the reactor at lower $\mathrm{C} / \mathrm{N}$ ratio of 5:1, acting as a monovalent cation, replaced the polyvalent cations in EPS, which prompted the release of EPS components to form new SMP. Furthermore, SMP at lower $\mathrm{C} / \mathrm{N}$ ratio possessed more $\mathrm{SMP}_{\mathrm{C}}$ (hydrophilic neutrals), higher $\mathrm{SMP}_{\mathrm{C}} / \mathrm{SMP}_{\mathrm{P}}$ ratio and smaller MW distribution. It gave rise to higher irreversible fouling resistance, which was well correlated with fouling profiles, i.e. higher TMP increment rate (Feng et al., 2012). Wu et al. (2012) indicated that compared to the control MBR (COD/N/P = 
100:8.7:3.5), an increased nitrogen or phosphorus loading in MBRs (low C/N-MBR $(\mathrm{COD} / \mathrm{N} / \mathrm{P}=100: 17.4: 3.5)$ or $\mathrm{C} / \mathrm{P}-\mathrm{MBR}(\mathrm{COD} / \mathrm{N} / \mathrm{P}=100: 8.7: 7.0))$ triggered apparent shifts of bacterial communities in a similar way. When the low $\mathrm{C} / \mathrm{N}-$ or $\mathrm{C} / \mathrm{P}-\mathrm{MBR}$ almost reached a steady state, biomass concentrations and EPS levels were comparable to those in the control MBR. In addition, dominant bacteria community were similar in both MBRs. Biomass samples from the low C/N-MBR and low C/P-MBR demonstrated larger flocs and lower membrane fouling rate as compared to the control MBR.

\subsubsection{Salinity and cations}

Previous studies indicated that high salt concentration broke the multivalent cation bridging among EPS within the sludge matrix, or reduced populations of protozoans, resulting in sludge deflocculation, and poor sludge quality, and compromised mechanical integrity and structure of sludge flocs. It reduced sludge filterability, whilst exacerbating membrane biofouling (De Temmerman et al., 2014; Jang et al., 2013). Jang et al. (2013) investigated MBR performance at various salinity conditions $(\mathrm{NaCl}$, 5-20 g/L) and found that the elevated salinity changed microbial composition, which influenced MBR performance. High salt concentrations increased fouling resistance due to the increased pore blocking and TMP increment rate, and this situation was mainly attributed to biomass properties (i.e. EPS, floc size and zeta potential). De Temmerman et al. (2014) asserted that the salt shock in the MBR $(\mathrm{NaCl}$ addition in the influent as a step up from 0.1 (background concentration) to $2 \mathrm{~g} / \mathrm{L}$ lasting for $5 \mathrm{~h}$ ) postponed the increase in submicron particles, SMP levels (proteins and polysaccharides), and irreversible fouling rate. There was no time delay in the shift in the supramicron particle size distribution towards smaller floc sizes and an increase in total fouling rate. 
In feed water, divalent cations (i.e. calcium, magnesium) improved aggregation and stabilization of matrix of biopolymers, microbes and sludge flocs through bridging negatively functional groups within EPS, which alleivated membrane biofouling. Normally, a relatively lower monovalent to divalent cation ratio $(<2: 1)$ but higher molar ratio of $\mathrm{Mg}: \mathrm{Ca}(>1: 1)$ favours floc agglomeration (Arabi and Nakhla, 2009).

\subsection{Membrane characteristics}

Membrane characteristics (e.g. materials, morphology, pore size, zeta potential, hydrophobicity/hydrophibicity affinity) are the principal factors affecting membrane biofouling. A current study from Nittami et al. (2014) revealed that when using the municipal wastewater treatment plant (WWTP) sludge which showed higher hydrophobicity, a dense cake layer formation on the membrane and higher TMP increase rate were achieved in the MBR with an immersed hydrophilic membrane than those for the MBR with an immersed hydrophobic membrane. However, for the labreactor sludge with lower hydrophobicity, the application of hydrophobic membrane triggered faster TMP increment. Thus, the effects of membrane surface hydrophilicity on membrane fouling were associated with the hydrophobicity of suspend sludge. It should be also noted that surface hydrophilicity/hydrophobicity of membranes was an essential factor for the interaction between membrane and foulants when the two contacting surfaces are infinite planar. However, when foulants are spherical particles as indicated by Zhang et al. (2015b), a different conclusion is reached. The interfacial interaction between sludge foulants and membranes was more remarkably affected by membrane surface zeta potential and roughness than membrane hydrophilicity/ hydrophobicity. 
Membrane fouling control is possible for membranes with relatively higher zeta potential and certain roughness, which increased the strength of the electrostatic double layer interaction and the energy barrier, and consistently maintained the total repulsive interaction, respectively. Dizge et al. (2011b) investigated the type and pore size of membranes on membrane fouling employing cellulose acetate (CA), polyethersulfone (PES), mixed ester (ME), polycarbonate (PC) membranes with three different pore sizes $(0.40-0.45,0.22,0.10 \mu \mathrm{m})$ in cross-flow microfiltration experiments. When the pore sizes of the membranes decreased (e.g. PES and ME), $R_{P}$ decreased as larger flocs were deposited on the surface of these membranes to form a filter cake or they clogged membrane pore entrances instead of passing through the pores. Concentration polarisation resistance was higher in the case of PES and ME membranes with smaller pore sizes, which was resulted from adsorption of soluble fraction of microbial products (carbohydrate and protein) onto the membrane surface. When compared to the clean membranes, the surface of fouled CA, PES and ME membranes indicated less roughness (smoother) because their surface cavities were covered by the microbial flocs.

Through evaluating effects of membrane pore size, surface porosity, pore morphology, and hydrophobicity on membrane fouling, it was suggested that less fouling could be achieved for the membrane with higher hydrophilic property, asymmetric structure, interconnected pore morphology, relatively large pore size and high surface porosity (van der Marel et al., 2010).

\section{Biofouling control strategies}

\subsection{Membrane cleaning}


Currently, membrane cleaning is classified into four types, namely, physical, chemical, physico-chemical and biological/biochemical in view of fouling removal mechanisms or the used cleaning agents. Physical and/or chemical cleaning methods could damage membrane properties, encourage the release of chemical reagents and the formation of cleaning by-products, which are detrimental to membranes, the environment, microbial community and cell activity. To overcome the issues of above cleaning approaches, biological/biochemical cleaning (e.g. mild cleaning alternatives, such as enzymatic cleaning, energy uncoupling and quorum quenching) has also been widely employed for the removal of membrane foulants. These methods are more efficient in decreasing biofilm formation with less adverse effects on microbial activity, microbial community, and membrane properties (Wang et al., 2014).

\subsection{Addition of media}

The direct addition of biomass carriers into MBRs could improve characteristics of mixed liquor and cake layer, thus alleviating membrane fouling. Jin et al. (2013) elucidated that ceramic MBR with suspended carriers (AnoxKaldnes, K1 carriers) having relatively low density and large size contained larger biomass flocs, less SMP and less EPS than that without the carriers. Furthermore the biomass carriers can reduce the cake layer on membrane surface but only slightly affect pore blocking.

The fresh powdered activated carbon (PAC) in a submerged MBR at relatively high concentrations eliminated EPS, SMP, fine colloids, polysaccharides, total organic carbon (TOC) and planktonic cells in the supernatant of mixed liquor by synergistic effects of adsorption, decomposition, and biodegradation. Furthermore, PAC promoted the production of large, strong and dense sludge flocs, which limited deposition of 
particles on the membranes and release of foulants, and retarded gel layer formation.

The fresh PAC could also accelerate the combined effects of collision and adsorption on the membrane surface. Consequently, adding PAC led to less membrane pore blocking, formation of a more porous, less compact and more stable cake layer on membrane surface, lower fouling rate, longer lifespan of membrane, and less energy consumption. Another advantage took the form of lower operating costs for cleaning the membrane or replacing it (Jamal Khan et al., 2012; Ng et al., 2013; Skouteris et al., 2015).

When compared to the conventional MBR (CMBR), sponge in the SSMBR reduced TMP development rate, and sustained good microbial activity and stable sludge volume index (SVI) value (Nguyen et al., 2012b). Deng et al. (2014) elucidated that sponge reduced EPS and SMP, lowered biomass growth, sludge viscosity and growth of filamentous bacteria, increased zeta potential and relative hydrophobicity $(\mathrm{RH})$, and enlarged sludge floc size, thus reducing $\mathrm{R}_{\mathrm{C}}, \mathrm{R}_{\mathrm{P}}$ and membrane fouling propensity in the SSMBR.

Other kinds of additives such as diatomite and clinoptilolite have successfully been employed in MBRs for membrane fouling reduction. They enlarged sludge floc size, increased MLSS, reduced foulants (e.g. dissolved organic matter (DOM)) in mixed liquor, and enhanced sludge settleability through the combined effects of adsorption and co-precipitation on fine colloids and DOM (Rezaei and Mehrnia, 2014; Yang et al., 2010).

\subsection{Addition of flocculants}

Adding different kinds of flocculants in MBRs could alter the properties of activated sludge and cake layer and lead to enhanced membrane performance. The 
effects of inorganic flocculants $\left(\mathrm{FeCl}_{3}\right.$ and polyaluminium chloride $\left.(\mathrm{PACl})\right)$ and natural organic flocculant (chitosan) on the performance of a submerged MBR were evaluated by Guo et al. (2010) in short-term experiments. The results suggested that MBR with addition of natural organic flocculants displayed relatively constant sludge volume indexes and higher specific oxygen uptake rates. Lower SMP levels and membrane fouling rates were achieved when applying inorganic flocculants in MBR. Zhang et ál. (2014) pointed out that at high salt shock, application of organic flocculant (especially MPE50) could increase floc size, relative hydrophobicity, zeta potential and bound EPS (especially EPS $S_{P}$, and reduce SMP by entrapping onto flocs, thus effectively mitigating membrane fouling.

Nguyen et al. (2010) showed the effectiveness of a new combined inorganicorganic flocculant (CIOF) of $\mathrm{FeCl}_{3}$ and MPE50 for membrane fouling control in an aerated submerged MBR. Moreover, a stable SVI and low TMP development rate were also realised by CIOF addition. Ji et al. (2014) presented that a polyacrylamide-starch composite flocculant (PAM-MGMS) in submerged MBRs not only demonstrated a long-lasting effect on SMP removal, but also extended the duration of floc size reduction caused by the irreversible deterioration of sludge flocs under continuous shear stress as well as the degradation of the modified starches. Therefore, PAM-MGMS could be suggesting as an additive for fouling control.

As the aforementioned flocculants exerted detrimental impacts on the environment and promoted the generation of "secondary pollutants" during wastewater reclamation and reuse, a new green bioflocculant $(\mathrm{GBF})$ as a safe biodegradable natural flocculant was developed by modifying a natural starch-based cationic flocculant (HYDRA Ltd., Hungary) (Ngo and Guo, 2009). A patented GBF was then developed at 
University of Technology, Sydney (UTS), namely Gemfloc ${ }^{\circledR}$. The results of a recent study (Deng et al., 2015) suggested that better sludge characteristics were given by the MBR with Gemfloc ${ }^{\circledR}$ addition (MBR-G), as demonstrated by less SMP, larger floc size, higher zeta potential and greater RH, lower growth of suspended biomass and lower sludge viscosity. Moreover, Gemfloc ${ }^{\circledR}$ reduced the contents of $\mathrm{EPS}_{\mathrm{P}}, \mathrm{SMP}$ and BPC in the membrane cake layer. Therefore the MBR-G realised lower membrane fouling potential, $\mathrm{R}_{\mathrm{C}}$ and $\mathrm{R}_{\mathrm{P}}$.

\subsection{Other methods}

As aerobic granule sludge featured an apparently large floc size with regular and compact structure, desirable settleability, high biomass, various bacteria community and high metabolic activity, Wang et al. (2013b) employed the aerobic granular sludge in a MBR for membrane fouling control at a high flux of $20 \mathrm{~L} / \mathrm{m}^{2} \cdot \mathrm{h}$. The results implied that in comparison to the MBRs with flocculent sludge, bulking sludge and smaller aerobic granular sludge (average diameter of $434 \mu \mathrm{m}$ ), the good aerobic granular sludge (larger average diameter of $903 \mu \mathrm{m}$ ) in the MBR significantly extended the filtration duration and reduced membrane fouling. Membrane fouling in the aerobic granular sludge was mainly attributed to $\mathrm{R}_{\mathrm{P}}$, while $\mathrm{R}_{\mathrm{C}}$ dominated the filtration resistance for flocculent sludge or bulk sludge due to the deposition of small particles on membrane surface, which prompted serious cake fouling. Recent studies also focused on the development of electro-MBRs (e-MBRs) for fouling minimisation. A recent study by Zhang et al. (2015c) revealed that a low-voltage electro-MBR (e-MBR) using stainless steel mesh as the anode, namely Fe-MBR, lowered TMP, decreased irreversible fouling and enhanced pollutant removals as compared to another e-MBR with titanium anodes (Ti-MBR) and 
one MBR without an electrical field. The electrical field exerted the electrical field force on negatively charged foulants, which moderated their tight attachment on the membrane surface and helped remove the fouling layer. Additionally the release of iron resulted in the reduction of TOC and polysaccharides of SMPs. Therefore less irreversible fouling and lower overall fouling rate were realised in the Fe-MBR.

\section{Challenges and perspectives}

Combining MBR with other technologies has been considered as a promising research trend. Although the current literature and discoveries have focused on this approach, a comprehensive biofouling framework needs to be developed. Thus, more efforts should be made to thoroughly analyse different MBR systems' impact on biofouling (including the above-mentioned integrated MBRs). The advanced biofouling mitigation methods could be created based on the aforementioned studies. More specifically, characterisation of bacterial communities and MW fractions of foulants (EPS, SMP, and BPC) in both mixed liquor and cake layer, and biocake architecture should be done when operating integrated MBRs. It would be also interesting to conduct the meso-scale analyses and studies on micro-interfacial process in these integrated MBRs to have more in-depth understanding of membrane fouling behaviour. Apart from that, the effects of salt and temperature shocks on the performance of these integrated MBRs must be carried out in detail to evaluate their feasibility for biofouling control under stressful conditions. Future studies could be devoted to combining the SSMBR or the SSMBR-G with biological/biochemical cleaning methods into one bioreactor, i.e. immobilising the quorum-quenching bacteria into a sponge. Moreover, 
the development of novel or modified flocculants and biomass carriers (e.g. using sponge) is to be encouraged in future studies.

\section{Conclusions}

This review presented the current achievements in key biofouling factors and recent developments in biofouling control strategies. BPC, EPS and SMP concentrations and their compositions largely influenced sludge properties and membrane fouling behaviour. Smaller floc size deteriorated membrane permeability.

The optimum MLSS level ( $<10 \mathrm{~g} / \mathrm{L})$, SRT $(20-40 \mathrm{~d})$ and temperature $\left(15-30^{\circ} \mathrm{C}\right)$ should be maintained to minimize membrane fouling. The impacts of membrane properties were partially determined by sludge characteristics and feedwater characteristics. The integration of MBR with other approaches could effectively enhance MBR performance. Future work should elucidate fouling behaviour in integrated MBRs more clearly.

\section{Authors' note}

Two Tables S1 and S2 are included in the supplementary material.

\section{Acknowledgement}

The authors are grateful for the research collaboration between University of Technology Sydney with Tianjin Polytechnic University and Tongji University on MBRC. The supports from the Opening Research Fund of State Key Laboratory of Hollow Fiber Membrane Materials and Processes, 2016 (M3-201502) and the joint University of Technology Sydney-China Scholarship Council (UTS-CSC) Doctor of Philosophy (Ph.D.) Scholarship are appreciated. 


\section{References}

1. Al-Halbouni, D., Traber, J., Lyko, S., Wintgens, T., Melin, T., Tacke, D., Janot, A., Dott, W., Hollender, J., 2008. Correlation of EPS content in activated sludge at different sludge retention times with membrane fouling phenomena. Water Res. 42, 1475-1488.

2. Arabi, S., Nakhla, G., 2009. Impact of magnesium on membrane fouling in membrane bioreactors. Sep. Purif. Technol. 67, 319-325.

3. Azami, H., Sarrafzadeh, M.H., Mehrnia, M.R., 2011. Fouling in membrane bioreactors with various concentrations of dead cells. Desalination 278, 373-380.

4. Babatsouli, P., Palogos, I., Michalodimitraki, E., Costa, C., Kalogerakis, N., 2014. Evaluation of a MBR pilot treating industrial wastewater with a high COD/N ratio. J. Chem. Technol. Biotechnol. 90, 26-33.

5. Bani-Melhem, K., Al-Qodah, Z., Al-Shannag, M., Qasaimeh, A., Qtaishat, M.R., Alkasrawi, M., 2015. On the performance of real grey water treatment using a submerged membrane bioreactor system. J. Membr. Sci. 476, 40-49.

6. Bitton, G., 2005. Microbiological aspect of drinking water distribution, in: Bitton, G. (Eds.), Wastewater microbiology. John Wiley \& Sons, Inc., Hoboken, New Jersey, pp. 421-425.

7. Braak, E., Alliet, M., Schetrite, S., Albasi, C., 2011. Aeration and hydrodynamics in submerged membrane bioreactors. J. Membr. Sci. 379, 1-18.

8. Chen, W., Liu, J., Xie, F., 2012. Identification of the moderate SRT for reliable operation in MBR. Desalination 286, 263-267.

9. Damayanti, A., Ujang, Z., Salim, M.R., Olsson, G., 2011. The effect of mixed liquor suspended solids (MLSS) on biofouling in a hybrid membrane bioreactor for 
the treatment of high concentration organic wastewater. Water Sci. Technol. 63, $1701-1706$.

10. Deng, L.J., Guo, W.S., Ngo, H.H., Zhang, J., Liang, S., Xia, S., Zhang, Z., Li, J., 2014. A comparison study on membrane fouling in a sponge-submerged membrane bioreactor and a conventional membrane bioreactor. Bioresour. Technol. 165, $69-74$.

11. Deng, L.J., Guo, W.S., Ngo, H.H., Zuthi, M.F.R., Zhang, J., Liang, S., Li, J., Wang, J., Zhang, X., 2015. Membrane fouling reduction and improvement of sludge characteristics by bioflocculant addition in submerged membrane bioreactor. Sep. Purif. Technol. 156, 450-458.

12. De Temmerman, L., Maere, T., Temmink, H., Zwijnenburg, A., Nopens, I., 2014. Salt stress in a membrane bioreactor: dynamics of sludge properties, membrane fouling and remediation through powdered activated carbon dosing. Water Res. 63, $112-124$.

13. De Temmerman, L., Maere, T., Temmink, H., Zwijnenburg, A., Nopens, I., 2015. The effect of fine bubble aeration intensity on membrane bioreactor sludge characteristics and fouling. Water Res. 76, 99-109.

14. Di Bella, G., Trapani, D.D., Torregrossa, M., Viviani, G., 2013. Performance of a MBR pilot plant treating high strength wastewater subject to salinity increase: Analysis of biomass activity and fouling behaviour. Bioresour. Technol. 147, 614-618.

15. Dizge, N., Koseoglu-Imer, D.Y., Karagunduz, A., Keskinler, B., 2011a. Effects of cationic polyelectrolyte on filterability and fouling reduction of submerged membrane bioreactor (MBR). J. Membr. Sci. 377, 175-181. 
16. Dizge, N., Soydemir, G., Karagunduz, A., Keskinler, B., 2011b. Influence of type and pore size of membranes on cross flow microfiltration of biological suspension. J. Membr. Sci. 366, 278-285.

17. Domínguez, L., Cases, V., Birek, C., Rodríguez, M., Prats, D., 2012. Influence of organic loading rate on the performance of ultrafiltration and microfiltration membrane bioreactors at high sludge retention time. Chem. Eng. J. 181-182, $132-143$.

18. Dreszer, C., Vrouwenvelder, J.S., Paulitsch-Fuchs, A.H., Zwijnenburg, A., Kruithof, J.C., Flemming, H.C., 2013. Hydraulic resistance of biofilms. J. Membr. Sci. 429, 436-447.

19. Drews, A., 2010. Membrane fouling in membrane bioreactors-characterisation, contradictions, cause and cures. J. Membr. Sci. 363, 1-28.

20. Duan, L., Song, Y., Yu, H., Xia, S.Q., Hermanowicz, S.W., 2014. The effect of solids retention times on the characterization of extracellular polymeric substances and soluble microbial products in a submerged membrane bioreactor. Bioresour. Technol. 163, 395-398.

21. Faust, L., Temmink, H., Zwijnenburg, A., Kemperman, A.J.B., Rijnaarts, H.H.M., 2014. Effect of dissolved oxygen concentration on the bioflocculation process in high loaded MBRs. Water Res. 66, 199-207.

22. Feng, S., Zhang, N., Liu, H., Du, X., Liu, Y., Lin, H., 2012. The effect of COD/N ratio on process performance and membrane fouling in a submerged bioreactor. Desalination 285, 232-238. 
23. Gao, D.W., Fu, Y., Tao, Y., Li, X.X., Xing, M., Gao, X.H., Ren, N.Q., 2011. Linking microbial community structure to membrane biofouling associated with varying dissolved oxygen concentrations. Bioresour. Technol. 102, 5626-5633.

24. Gao, D.W., Tao, Y., An, R., 2012. Digested sewage treatment using membranebased process at different hydraulic retention times. Desalination 286, 187-192.

25. Gao, W.J., Han, M.N., Qu, X., Xu, C., Liao, B.Q., 2013a. Characteristics of wastewater and mixed liquor and their role in membrane fouling. Bioresour. Technol. 128, 207-214.

26. Gao, D.W., Wen, Z.D., Li, B., Liang, H., 2013b. Membrane fouling related to microbial community and extracellular polymeric substances at different temperatures. Bioresour. Technol. 143, 172-177.

27. Guo, W.S., Ngo, H.H., Vigneswaran, S., Dharmawan, F., Nguyen, T.T., Aryal, R., 2010. Effect of different flocculants on short-term performance of submerged membrane bioreactor. Sep. Purif. Technol. 70, 274-279.

28. Guo, W.S., Ngo, H.H., Li, J.X., 2012. A mini-review on membrane fouling. Bioresour. Technol. 122, 27-34.

29. Hong, H., Zhang, M., He, Y., Chen, J., Lin, H., 2014. Fouling mechanisms of gel layer in a submerged membrane bioreactor. Bioresour. Technol. 166, 295-302.

30. Jamal Khan, S., Visvanathan, C., Jegatheesan, V., 2012. Effect of powdered activated carbon (PAC) and cationic polymer on biofouling mitigation in hybrid MBRs. Bioresour. Technol. 113, 165-168.

31. Jang, D., Hwang, Y., Shin, H., Lee, W., 2013. Effects of salinity on the characteristics of biomass and membrane fouling in membrane bioreactors. Bioresour. Technol. 141, 50-56. 
32. Ji, J., Li, J., Qiu, J., Li, X., 2014. Polyacrylamide-starch composite flocculant as a membrane fouling reducer: key factors of fouling reduction. Sep. Purif. Technol. $131,1-7$.

33. Jin, L., Ong, S.L., Ng, H.Y., 2013. Fouling control mechanism by suspended biofilm carriers addition in submerged ceramic membrane bioreactors. J. Membr. Sci. 427, 250-258.

34. Kaya, Y., Ersan, G., Vergili, I., Z. Gönder, B., Yilmaz, G., Dizge, N., Aydiner, C., 2013. The treatment of pharmaceutical wastewater using in a submerged membrane bioreactor under different sludge retention times. J. Membr. Sci. 442, 72-82.

35. Kornboonraksa, T., Lee, S.H., 2009. Factors affecting the performance of membrane bioreactor for piggery wastewater treatment. Bioresour. Technol. 100, $2926-2932$.

36. Lay, W.C.L., Liu, Y., Fane, A.G., 2010. Impacts of salinity on the performance of high retention membrane bioreactors for water reclamation: a review. Water Res. $44,21-40$.

37. Le-Clech, P., 2010. Membrane bioreactors and their uses in wastewater treatments. Appl. Microbiol. Biot. 88, 1253-1260.

38. Lee, S., Kim, M.H., 2013. Fouling characteristics in pure oxygen MBR process according to MLSS concentrations and COD loadings. J. Membr. Sci. 428, 323-330.

39. Li, J., Yang, F., Liu, Y., Song, H., Li, D., Cheng, F., 2012. Microbial community and biomass characteristics associated severe membrane fouling during start-up of a hybrid anoxic-oxic membrane bioreactor. Bioresour. Technol. 103, 43-47. 
40. Lin, H.J., Gao W.J, Meng, F.G., Liao B.Q., Leung, K.T., Zhao, L.H., Chen, J.R., Hong, H.C., 2012. Membrane bioreactors for industrial wastewater treatment: a critical review. Crit. Rev. Env. Sci. Technol. 42, 677-740.

41. Liu, Y., Liu, Z., Zhang, A., Chen, Y., Wang, X., 2012. The role of EPS concentration on membrane fouling control: comparison analysis of hybrid membrane bioreactor and conventional membrane bioreactor. Desalination 305, $38-43$.

42. Lousada-Ferreira, M., Geilvoet, S., Moreau, A., Atasoy, E., Krzeminski, P., van Nieuwenhuijzen, A., van der Graaf, J., 2010. MLSS concentration: still a poorly understood parameter in MBR filterability. Desalination 250, 618-622.

43. Meng, F.G., Shi, B.Q., Yang, F.L., Zhang, H.M., 2007. New insights into membrane fouling in submerged membrane bioreactor based on rheology and hydrodynamics concepts. J. Membr. Sci. 302, 87-94.

44. Meng, F., Chae, S.R., Drews, A., Kraume, M., Shin, H.S., Yang, F., 2009. Recent advances in membrane bioreactors (MBRs): membrane fouling and membrane material. Water Res. 43, 1489-1512.

45. Mutamim, N.S.A., Noor, Z.Z., Hassan, M.A.A., Olsson, G., 2012. Application of membrane bioreactor technology in treating high strength industrial wastewater: a performance review. Desalination 305, 1-11.

46. Mutamim, N.S.A., Noor, Z.Z., Hassan, M.A.A., Yuniarto, A., Olsson, G., 2013. Membrane bioreactor: applications and limitations in treating high strength industrial wastewater. Chem. Eng. J. 225, 109-119. 
47. Ng, C.A., Sun, D., Bashir, M.J.K., Wai, S.H., Wong, L.Y., Nisar, H., Wu, B., Fane, A.G., 2013. Optimization of membrane bioreactors by the addition of powdered activated carbon. Bioresour. Technol. 138, 38-47.

48. Ngo, H.H., Guo, W.S., 2009. Membrane fouling control and enhanced phosphorus removal in an aerated submerged membrane bioreactor using modified green bioflocculant. Bioresour. Technol. 100, 4289-4291.

49. Nguyen, T.T., Guo, W.S., Ngo, H.H., Vigneswaran, S., 2010. A new combined inorganic-organic flocculant (CIOF) as a performance enhancer for aerated submerged membrane bioreactor. Sep. Purif. Technol. 75, 204-209.

50. Nguyen, T., Roddick, F.A., Fan, L., 2012a. Biofouling of water treatment membranes: a review of the underlying causes, monitoring techniques and control measures. Membranes 2, 804-840.

51. Nguyen, T.T., Ngo, H.H., Guo, W.S., Li, J.X., Listowski, A., 2012b. Effects of sludge concentrations and different sponge configurations on the performance of a sponge-submerged membrane bioreactor. Appl. Biochem. Biotechnol.167, $1678-1687$.

52. Nittami, T., Tokunaga, H., Satoh, A., Takeda, M., Matsumoto, K., 2014. Influence of surface hydrophilicity on polytetrafluoroethylene flat sheet membrane fouling in a submerged membrane bioreactor using two activated sludges with different characteristics. J. Membr. Sci. 463, 183-189.

53. Pan, J.R., Su, Y.C., Huang, C., Lee, H.C., 2010. Effect of sludge characteristics on membrane fouling in membrane bioreactors. J. Membr. Sci. 349, 287-294.

54. Rezaei, M., Mehrnia, M.R., 2014. The influence of zeolite (clinoptilolite) on the performance of a hybrid membrane bioreactor. Bioresour. Technol. 158, 25-31. 
55. Shen, Y., Zhao, W., Xiao, K., Huang, X., 2010. A systematic insight into fouling propensity of soluble microbial products in membrane bioreactors based on hydrophobic interaction and size exclusion. J. Membr. Sci. 346, 187-193.

56. Shen, Y.X., Xiao, K., Liang, P., Sun, J.Y., Sai, S.J., Huang, X., 2012.

Characterization of soluble microbial products in 10 large-scale membrane bioreactors for municipal wastewater treatment in China. J. Membr. Sci. 415-416, $336-345$.

57. Shen, L.G., Lei, Q., Chen, J.R., Hong, H.C., He, Y.M., Lin, H.J., 2015. Membrane fouling in a submerged membrane bioreactor: impacts of floc size. Chem. Eng. J. $269,328-334$.

58. Skouteris, G., Saroj, D., Melidis, P., Hai, F.I., Ouki, S., 2015. The effect of activated carbon addition on membrane bioreactor processes for wastewater treatment and reclamation-a critical review. Bioresour. Technol. 185, 399-410.

59. Sun, F.Y., Wang, X.M., Li, X.Y., 2008. Visualisation and characterisation of biopolymer clusters in a submerged membrane bioreactor. J. Membr. Sci. 325, 691-697.

60. Tian, Y., Chen, L., Zhang, S., Cao, C., Zhang, S., 2011a. Correlating membrane fouling with sludge characteristics in membrane bioreactors: an especial interest in EPS and sludge morphology analysis. Bioresour. Technol. 102, 8820-8827.

61. Tian, Y., Chen, L., Zhang, S., Zhang, S., 2011b. A systematic study of soluble microbial products and their fouling impacts in membrane bioreactors. Chem. Eng. J. 168, 1093-1102. 
62. Tian, Y., Su, X., 2012. Relation between the stability of activated sludge flocs and membrane fouling in MBR: under different SRTs. Bioresour. Technol. 118, $477-482$.

63. van der Marel, P., Zwijnenburg, A., Kemperman, A., Wessling, M., Temmink, H., van der Meer, W., 2010. Influence of membrane properties on fouling in submerged membrane bioreactors. J. Membr. Sci. 348, 66-74.

64. Van den Broeck, R., Van Dierdonck, J., Nijskens, P., Dotremont, C., Krzeminski, P., van der Graaf, J.H.J.M., van Lier J.B., Van Impe J.F.M., Smets, I.Y., 2012. The influence of solids retention time on activated sludge bioflocculation and membrane fouling in a membrane bioreactor (MBR). J. Membr. Sci. 401-402, 48-55.

65. Wang, X.M., Li, X.Y., 2008. Accumulation of biopolymer clusters in a submerged membrane bioreactor and its effect on membrane fouling. Water Res. 42, 855-862.

66. Wang, Q., Wang, Z., Wu, Z., Ma, J., Jiang, Z., 2012. Insights into membrane fouling of submerged membrane bioreactors by characterizing different fouling layers formed on membrane surfaces. Chem. Eng. J. 179, 169-177.

67. Wang, Z.W., Han, X.M., Ma, J.X., Wang, P., Mei, X.J., Wu, Z.C., 2013a. Recent advances in membrane fouling caused by extracellular polymeric substances: a mini-review. Desalin. Water Treat. 51, 5121-5131.

68. Wang, Y., Zhong, C., Huang, D., Wang, Y., Zhu, J., 2013b. The membrane fouling characteristics of MBRs with different aerobic granular sludges at high flux. Bioresour. Technol. 136, 488-495.

69. Wang, Z., Ma, J., Tang, C.Y., Kimura, K., Wang, Q., Han, X., 2014. Membrane cleaning in membrane bioreactors: a review. J. Membr. Sci. 468, 276-307. 
70. Wu, B., Fane, A.G., 2012. Microbial relevant fouling in membrane bioreactors: influencing factors, characterization, and fouling control. Membrane 2, 565-584.

71. Wu, J., Huang, X., 2009. Effect of mixed liquor properties on fouling propensity in membrane bioreactors. J. Membr. Sci. 342, 88-96.

72. Wu, S.C., Lee, C.M., 2011. Correlation between fouling propensity of soluble extracellular polymeric substances and sludge metabolic activity altered by different starvation conditions. Bioresour. Technol. 102, 5375-5380.

73. Wu, B., Yi, S., Fane, A.G., 2011a. Microbial behaviors involved in cake fouling in membrane bioreactors under different solids retention times. Bioresour. Technol. $102,2511-2516$.

74. Wu, B., Yi, S., Fane, A.G., 2011b. Microbial community developments and biomass characteristics in membrane bioreactors under different organic loadings. Bioresour. Technol. 102, 6808-6814.

75. Wu, B., Fane, A.G., 2012. Microbial relevant fouling in membrane bioreactors: influencing factors, characterization, and fouling control. Membrane 2, 565-584.

76. Wu, B., Yi, S., Fane, A.G., 2012. Effect of substrate composition (C/N/P ratio) on microbial community and membrane fouling tendency of biomass in membrane bioreactors. Sep. Sci. Technol. 47, 440-445.

77. Xia, S., Li, J., He, S., Xie, K., Wang, X., Zhang, Y., Duan, L., Zhang, Z., 2010. The effect of organic loading on bacterial community composition of membrane biofilms in a submerged polyvinyl chloride membrane bioreactor. Bioresour. Technol. 101, 6601-6609. 
78. Yang, X.L., Song, H.L., Lu, J.L., Fu, D.F., Cheng, B., 2010. Influence of diatomite addition on membrane fouling and performance in a submerged membrane bioreactor. Bioresour. Technol. 101, 9178-9184.

79. Yao, M., Ladewig, B., Zhang, K., 2011. Identification of the change of soluble microbial products on membrane fouling in membrane bioreactor (MBR). Desalination 278, 126-131.

80. Ye, F., Ye, Y., Li, Y., 2011. Effect of $\mathrm{C} / \mathrm{N}$ ratio on extracellular polymeric substances (EPS) and physicochemical properties of activated sludge flocs. J. Hazard. Mater. 188, 37-43.

81. Zhang, H., Gao, Z., Zhang, L., Song, L., 2014. Performance enhancement and fouling mitigation by organic flocculant addition in membrane bioreactor at high salt shock. Bioresour. Technol. 164, 34-40.

82. Zhang, X., Yue, X., Liu, Z., Li, Q., Hua, X., 2015a. Impacts of sludge retention time on sludge characteristics and membrane fouling in a submerged anaerobicoxic membrane bioreactor. Appl. Microbiol. Biotechnol. 99, 4893-4903.

83. Zhang, M., Liao, B.Q., Zhou, X., He, Y., Hong, H., Lin, H., Chen, J., 2015 b. Effects of hydrophilicity/hydrophobicity of membrane on membrane fouling in a submerged membrane bioreactor. Bioresour. Technol. 175, 59-67.

84. Zhang, J., Satti, A., Chen, X., Xiao, K., Sun, J., Yan, X., Liang, P., Zhang, X., Huang, X., 2015c. Low-voltage electric field applied into MBR for fouling suppression: performance and mechanisms. Chem. Eng. J. 273, 223-230. 


\section{Figure captions}

Fig. 1. Schematic of biofilm formation on a surface (modified from Bitton, 2005)

Fig. 2. Schematic illustration of correlation between SMP and BPC in MBR 


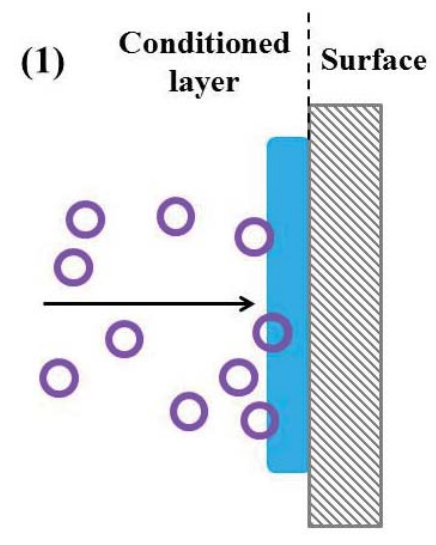

(3)

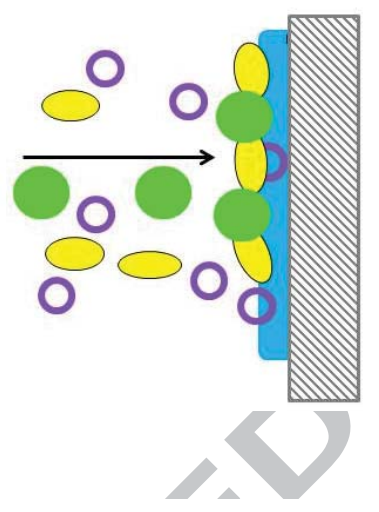

(5)

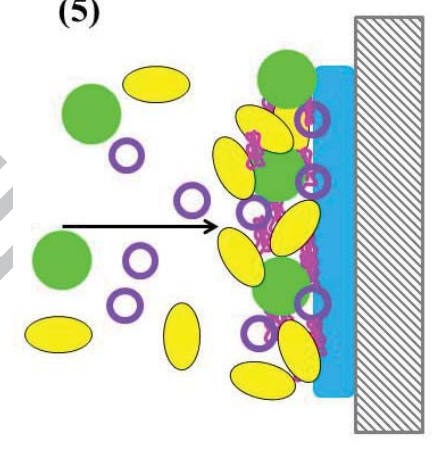

(2)

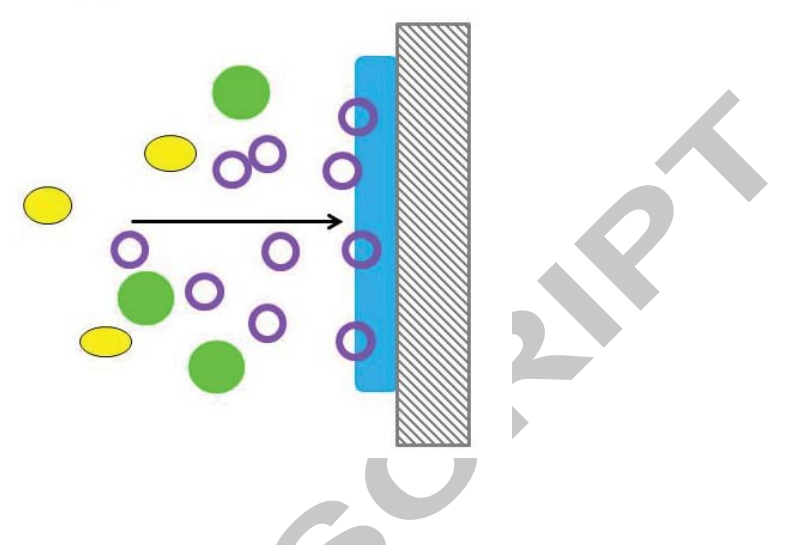

(4)

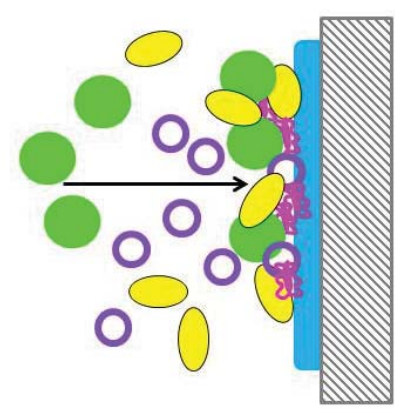

(6)

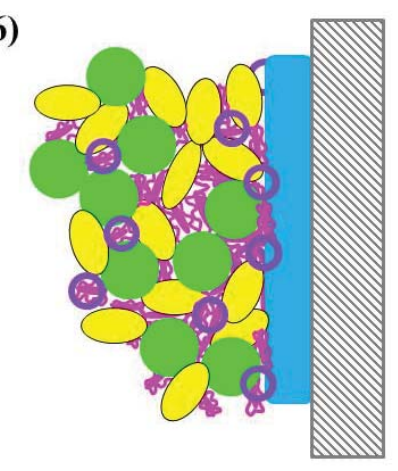

Organic matters $\bigcirc$ Microorganisms

Fig. 1. 


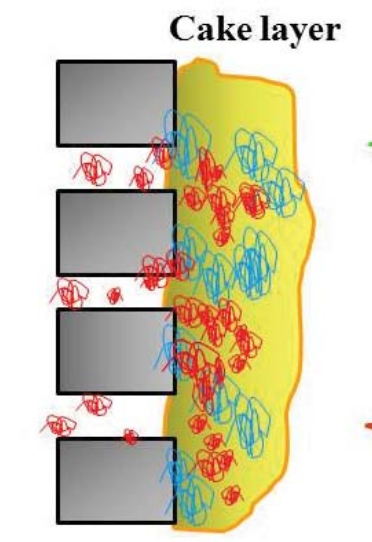

membrane

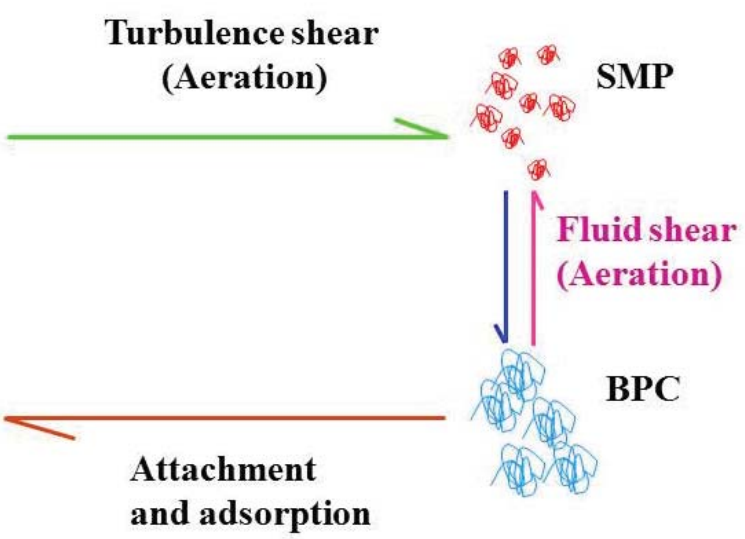

Activated sludge

Fig. 2. 
Table 1.

Effects of MLSS concentration on biofouling

\begin{tabular}{|c|c|c|c|}
\hline $\begin{array}{l}\text { Type of } \\
\text { wastewater }\end{array}$ & $\begin{array}{l}\text { MLSS } \\
\text { concentration }\end{array}$ & Effects on biofouling & References \\
\hline $\begin{array}{l}\text { Synthetic } \\
\text { wastewater }\end{array}$ & $3.0-25.0 \mathrm{~g} / \mathrm{L}$ & $\begin{array}{l}\text { At low MLSS levels }(<5.0 \mathrm{~g} / \mathrm{L}) \text {, less } \\
\text { membrane fouling was observed at the } \\
\text { elevated MLSS concentration, while fouling } \\
\text { rate was almost zero when MLSS } \\
\text { concentration increased to } 7.9 \mathrm{~g} / \mathrm{L} \text {; } \\
\text { When increasing MLSS concentration }(>10 \\
\text { g/L) by two times, fouling rates increased by } \\
\text { almost three times. Nine-fold increase in } \\
\text { fouling rate was obtained over a three-fold } \\
\text { increase in MLSS concentration }(>15 \mathrm{~g} / \mathrm{L}) \text {. }\end{array}$ & $\begin{array}{l}\text { Li et al., } \\
2012 ; \\
\text { Lee and } \\
\text { Kim, } 2013\end{array}$ \\
\hline $\begin{array}{l}\text { Real } \\
\text { wastewater }\end{array}$ & $2.3-20.0 \mathrm{~g} / \mathrm{L}$ & $\begin{array}{l}\text { - A slight change of permeation flux was } \\
\text { attained when increasing biomass } \\
\text { concentration within low MLSS range }(<4.1 \\
\text { g/L); } \\
\text { At higher MLSS concentration }(4.1-6.75 \\
\text { g/L), increasing MLSS notably decreased } \\
\text { permeate flux; } \\
\text { The increase in MLSS from } 5 \text { to } 20 \mathrm{~g} / \mathrm{L} \\
\text { reduced the critical flux by } 3 \text { times. }\end{array}$ & $\begin{array}{l}\text { Bani- } \\
\text { Melhem et } \\
\text { al., 2015; } \\
\text { Damayanti } \\
\text { et al., } 2011\end{array}$ \\
\hline
\end{tabular}


Table 2.

Effects of SRT on biofouling

\begin{tabular}{|c|c|c|}
\hline SRT & Effects on sludge characteristics and biofouling ${ }^{\mathrm{a}}$ & References \\
\hline $\begin{array}{l}3-50 \mathrm{~d} \\
(\mathrm{HRT}= \\
6-26 \mathrm{~h})\end{array}$ & $\begin{array}{l}\text { - Shorter SRT facilitated the accumulation of } \\
\text { carbohydrates and proteins of SMP and EPS in the } \\
\text { submerged MBR. In addition, it also increased the } \\
\text { amounts of small molecules (MW < } 1 \mathrm{kDa} \text { ) of SMP and } \\
\text { reduced macromolecules (MW }>30 \mathrm{kDa} \text { ) of EPS. More } \\
\text { undefined microbial by-product-like substances and } \\
\text { distinct O-H bonds in hydroxyl functional groups were } \\
\text { found with decreasing SRT; } \\
\text { - At lower SRT, MBR sludge featured poorer filterability } \\
\text { and settleability, higher RH, and more filamentous } \\
\text { bacteria. It led to more loose floc structure, poorer floc } \\
\text { stability, poorer bioflocculation of activated sludge and } \\
\text { generation of larger amounts of smaller aggregates; } \\
\text { More severe membrane fouling, less porous fouling layer } \\
\text { and a relative higher specific resistance were attained at } \\
\text { lower SRT (i.e. } 10 \text { and } 15 \mathrm{~d} \text { ). Besides, more distinct } \\
\text { fouling layer on the membrane was formed at lower SRT } \\
\text { (23 d), containing significantly higher concentrations of } \\
\text { deposited EPS ( } 40 \text {-fold higher for protein and 5-fold } \\
\text { higher for carbohydrate) than those at higher SRT ( } 40 \mathrm{~d} \text { ). }\end{array}$ & $\begin{array}{l}\text { Al-Halbouni et } \\
\text { al., 2008; Duan } \\
\text { et al., 2014; Tian } \\
\text { and Su, 2012; } \\
\text { Van den Broeck } \\
\text { et al., } 2012\end{array}$ \\
\hline
\end{tabular}

\footnotetext{
${ }^{\mathrm{a}}$ EPS, extracellular polymeric substances; $\mathrm{MW}$, molecular weight; $\mathrm{RH}$, relative hydrophobicity; SMP, soluble microbial products
} 


\section{Graphic abstract}

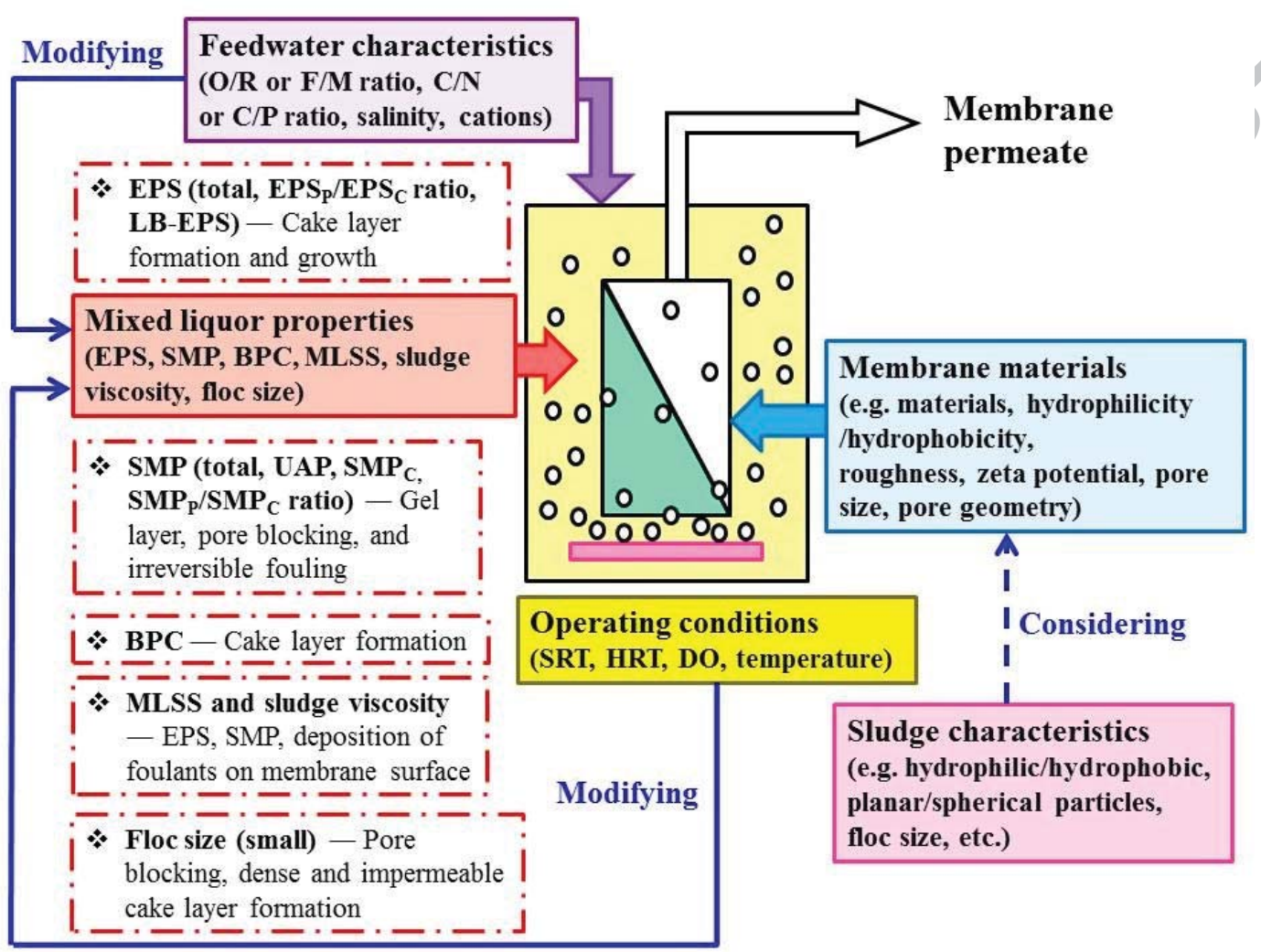




\section{Highlights}

- Biofouling has become a major issue during MBR operation.

- Various MBR biofouling factors and control strategies are reviewed.

- Sludge properties play a critical role in membrane biofouling potential.

- Adding sponge or bioflocculant into MBR achieves desirable fouling reduction.

- Development of integrated MBRs with novel flocculants and media is needed. 